\title{
EVOLUTION OF THE BIDEN ADMINISTRATION'S APPROACH TO IRAN NUCLEAR DEAL AND PROSPECTS FOR REGIONAL PEACE
}

\author{
Seyed Hossein Mousavian* \\ Princeton University \\ ORCID: 0000-0002-7215-0257 \\ Younes Mahmoudieh** \\ Institut Barcelona d'Estudis Internacionals \\ ORCID: 0000-0002-5102-1632 \\ (C) S.H.Mousavian, 2021 \\ (C) Yo.Mahmoudieh, 2021
}

DOI: $10.20542 / 2307-1494-2021-2-129-138$

\begin{abstract}
Public statements and a campaign promise made by the Joe Biden's team raised hopes of the U.S. return to the 2015 Iran nuclear deal, or Joint Comprehensive Plan of Action (JCPOA), early in his presidency. As a result, expectations of the sanctions relief and impending diplomatic breakthrough with Iran quickly mounted after President Biden's victory. However, a closer look at the emerging evidence reveals that the new administration initially intended to return to the JCPOA with a different Iran strategy, one of coercion and pressure. Due to former President Trump's "maximum pressure" campaign against Iran, the JCPOA was practically dead. It then had to be revived. The article inspects key factors that were successful in changing the Biden administration's policy towards a more realistic and cooperative approach. However, this delay on Biden's part was not without consequences and has major implications for relations with Iran, as well as the implementation of the JCPOA.
\end{abstract}

Keywords Iran, nuclear deal, Joint Comprehensive Plan of Action (JCPOA), United States, D.Trump, J.Biden, H.Rouhani, E.Raisi

\section{Название Эволюция подхода администрации Байдена к иранской ядерной сделке статьи и перспективы мира в регионе}

Аннотация Публичные заявления и обещания Дж.Байдена и его соратников во время предвыборной кампании 2020 г. возродили надежду на возврат США в состав

\footnotetext{
* Seyed Hossein Mousavian (Iran) is Middle East Security and Nuclear Policy Specialist at Princeton University, and a former Chief of Iran's National Security Foreign Relations Committee.

Сейед Хосейн Мусавян (Иран) - специалист по проблемам ближневосточной безопасности и ядерной политики Принстонского университета (США), бывший глава Комитета по международным отношениям Совета национальной безопасности Ирана.

** Younes Mahmoudieh (Iran) is a researcher at the Institut Barcelona d'Estudis Internacionals (IBEI).

Юнес Махмудие (Иран) - исследователь, Барселонский институт международных исследований, Барселона, Испания.
} 
участников иранской ядерной сделки - Совместного всеобъемлющего плана действий (СВПД) 2015 г. - на раннем этапе правления новой администрации. После победы Дж.Байдена на президентских выборах усилились ожидания ослабления санкций против Ирана и возможного дипломатического прорыва по ядерной сделке. Однако анализ выступлений представителей и документов администрации Байдена в начале ее пребывания у власти показывает, что ее первые шаги на этом направлении были продиктованы более жестким подходом, основанном на принуждении и давлении. Ранее политика «максимального давления» на Иран, избранная администрацией Д.Трампа, уже фрактически привела к развалу иранской ядерной сделки, которую теперь приходится возрождать. В статье рассмотрены фракторы, которые способствовали переходу администрации Дж.Байдена от первоначально более жесткого к более реалистичному подходу к этой проблеме, в большей степени нацеленному на международное сотрудничество. Тем не менее, промедление с возобновлением переговоров по ядерному соглашению с Ираном со стороны администрации Байдена не прошло бесследно, с точки зрения будущего американо-иранских отношений и выполнения условий СВПД.

Ключевые иранская ядерная сделка, Совместный всеобъемлющий план действий (СВПД), слова США, Д.Трамп, Дж.Байден, Х.Рухани, И.Раиси

In 2020, Joe Biden repeatedly publicly called for a return to the Joint Comprehensive Plan of Action (JCPOA) ${ }^{1}$ - a long-awaited agreement on the Iranian nuclear program reached in Vienna on 14 July 2015 between Iran and the "P5+1" (the five permanent members of the UN Security Council plus Germany, along with the European Union). In fact, it was one of Biden's major campaign promises in the presidential election where he competed against Donald Trump who had withdrawn the United States from the accords in May 2018. The JCPOA represented the foreign policy legacy of the Barack Obama administration where Biden had served. His strong defense of the accords and advocacy for the U.S. return to the JCPOA would seem natural and expected. After all, much of Biden's presidential victory was due to his association with Obama and his promise to reverse Trump's policies. Despite all this, an analysis of Biden's first few months in office and his administration's congressional statements discloses the new president's real aims and suggests a drift from Obama's hallmark foreign policy and security achievement: the 2015 JCPOA. Biden seemed to be gambling with fantasies and miscalculations left over from the Trump's era before seriously committing to diplomacy. This hesitation has proven costly and could undermine bilateral relations.

The U.S. evolving approach to nuclear negotiations with Iran has been well documented. Paul R. Pillar and his colleagues listed mistaken assumptions by members of the American foreign policy community that significantly hindered progress regarding Iranian nuclear negotiations in the past. ${ }^{2}$ Similarly, authors such as Ali Vaez ${ }^{3}$ and Daryl Kimball ${ }^{4}$ looked at why sanctions failed to limit Iran's nuclear program, while Kimball also explored why the 2015 Iranian nuclear deal was a successful, innovative solution that must be upheld. Along this vein, Trita Parsi in his book "Losing an Enemy: Obama, Iran, and the Triumph of Diplomacy" chronicles developments during the Obama administration that made it possible to achieve the JCPOA. ${ }^{5}$ President Trump's subsequent catastrophic mistakes were explored by Seyed Hossein Mousavian and Younes Mahmoudieh. ${ }^{6}$ 
After taking office in January 2021, President Biden faced many domestic challenges. The Capitol riots threatened his message of bipartisan unity, while undoing many of the Trump administration's policies such as rejoining the Paris climate accords, ending the "Travel Ban," accelerating the U.S.' vaccination rollout, and passing the "American Rescue Plan" took up the time and focus of the new president. Consequently, the new administration's Iran policy did not receive much priority. Meanwhile, the U.S. president's foreign policy team explored various options regarding extending the JCPOA negotiations and adding preconditions to rejoining the nuclear deal. ${ }^{7}$

On March 10, 2021, Secretary of State Anthony Blinken responded to questions on the Biden administration's foreign policy before the House Foreign Affairs Committee. A notable portion of these questions were dedicated to Iran. When responding to a question by Representative Ilhan Omar about prospects of the U.S. return to the JCPOA, Secretary Blinken stated: "If Iran returns to compliance, we will too; and then we will try to work on other issues that divide us, including lengthening and strengthening the agreement" ${ }^{8}$ There are important elements to consider in this statement. The mention of a "longer and stronger agreement" has been repeated by the Biden administration officials several times and closely resembles the official policy of the Trump administration who wished to negotiate a "better" deal with Iran. The Biden administration already seemed to be mentioning and pursuing a different agreement, in a startling contradiction to its earlier presidential campaign promises to return to the 2015 JCPOA.

When asked if he would commit to addressing the issue of Iran's ballistic missiles and human rights record alongside the JCPOA and whether he would consult with the U.S. Congress on these matters, the Secretary of State immediately obliged and said "Yes". The Biden administration intended to pursue negotiations about Iran's missile program and human rights record during nuclear talks. It is important to note that much of President Obama's success with Iran was due to his administration's readiness to separate nuclear negotiations from other issues. Iran has long resisted negotiations regarding its domestic affairs and continues to insist that its defense capabilities and regional activities are not for discussion. ${ }^{9}$ For this reason, in 2015 , the U.S. diplomats solely focused on Iran's nuclear activities and were thus able to achieve notable progress. However, Secretary Blinken's statements revealed a different approach taken by the Biden administration: nuclear negotiations to be resumed alongside addressing "attached" non-nuclear issues. This stance provoked Iran to insist that it would only negotiate issues related to the JCPOA. Consequently, valuable time for dialogue was lost.

In response to congressional concerns about upcoming "sunset provisions" 10 in the JCPOA, Blinken responded that it is the administration's intent to use the current agreement only as a platform for a new one - the one that would extend these sunset provisions and build on non-nuclear related issues that were not included in the original JCPOA. In his January 2021 confirmation hearing, Blinken also repeatedly envisioned a slower, extended process in regards to the JCPOA (in contrast, for instance, to the administration's quick action regarding the Paris climate accords). ${ }^{11}$ "We are a long way from" getting back into the deal, he said during his Senate confirmation hearings, because Washington would "have to evaluate whether [Iran was] actually making good if they say they are coming back into compliance with their obligations, and then would take it from there". ${ }^{2}$ Not only would the Biden administration be seeking a different agreement, but it would also refrain from being the first to act and would demand Iranian re-compliance before any real U.S. measures are 
taken. In essence, the Biden administration would not rush to re-enter the JCPOA and would first explore whether it could extract Iranian concessions, despite the United States being the first and only party to violate and exit the accords.

Wendy Sherman's confirmation hearing in the U.S. Senate, held on March 3, 2021, also provides insight on this matter. Sherman served as one of the chief nuclear negotiators in the Obama administration and became the Deputy Secretary of State of the Biden administration. When asked about the JCPOA's ability to ensure Iran does not acquire a nuclear weapon, Sherman offered a surprising response: "I would be glad to talk about how the JCPOA did create the assurance you are looking for, but it is really beside the point now because we are at a very different place. The geopolitics are very different in the region". ${ }^{13}$ This candid confession was surprising given that Sherman was one of the chief negotiations responsible for the 2015 JCPOA. She touched back on this theme again later in the hearing: "I would note that 2021 is not 2015, when the deal was agreed, nor 2016, when it was implemented. The facts on the ground have changed, the geopolitics of the region have changed, and the way forward must similarly change". Sherman's testimony even suggested that the new administration was no longer deeply invested in returning the 2015 JCPOA and was ready to move on.

A review of statements by top officials of the Biden administration shows that the United States was not serious about returning to or preserving the original JCPOA, but was instead focused on pursuing a new agreement and drawing out negotiations. The Biden administration planned to accumulate leverage to impose pressure on Iran: a tactic the Trump administration had employed earlier (and failed to achieve any results with). ${ }^{14}$

In the following months, Iran's tough response was crucial in dissuading the Biden administration from continuing its initial plans and convincing it to recommit to the JCPOA. The first impasse facing both countries in reviving the nuclear agreement was the issue on which party should or would act first. The United States initially insisted that Iran re-starts compliance before Washington relieves any sanctions and re-enters the deal. ${ }^{15}$ In turn, Iran insisted that the U.S.' violation of the accords put the weight of responsibility on Washington to act first. ${ }^{16}$ As a symbol of compromise, a "step by step" approach was mentioned early on by both sides. According to this approach, a mutually agreed roadmap would guide both sides to take gradual steps towards returning to full compliance. ${ }^{17}$ However, the Biden administration's tough stance resulting from its miscalculations backfired. On March 21, 2021, Iran's Supreme Leader Ayatollah Khamenei announced that there would be no gradual return to the agreement, ruling out the "step by step approach," and that Iran would re-enter compliance only after the United States fully lifts all nuclear sanctions and Iran verifies its actions. ${ }^{18}$ Iranian diplomats who had previously voiced optimism towards the proposed "step-by-step" mechanism responded by hardening their rhetoric and likewise insisting on full American sanctions relief before any Iranian action. ${ }^{19}$ The window for certain compromises appeared to have closed.

This firm stance by Iran's leadership was followed by a dramatic increase in uranium enrichment in April 2021. ${ }^{20}$ Following a suspected Israeli attack on "Natanz" nuclear site in Iran, President Hassan Rouhani announced that Iran would produce 60 percent enriched uranium (up from 20 percent previously) and would also install 1000 additional centrifuges at "Natanz" while replacing damaged "IR-1"s (Iran's oldest and least efficient centrifuges) with advanced "IR-6" models. ${ }^{21}$ This response increased pressure on the United States to find a swift diplomatic solution to the nuclear issue and demonstrated that Iran's leadership would 
not be content to engage in protracted talks and was serious about its warnings regarding stalling the negotiation process. Sabotage attempts have repeatedly failed to constrict Iran's nuclear program and have often provoked a reinvigorated response with increased enrichment.

The reigning belief in Tehran is that the U.S. policies towards Iran are rooted in force and bullying. Consequently, many in Iran's political establishment are pessimistic about engaging with the United States under international norms and believe that an aggressive approach is the only path to achieve American flexibility and concessions. ${ }^{22}$ During the Trump presidency, Iran responded to the "maximum pressure" campaign with "resistance" and was thus able to achieve success: as top U.S. officials candidly admitted later, maximum pressure had failed. ${ }^{23}$ During the early stages of the Biden presidency, some U.S. officials insisted on capitalizing on the Trump era sanctions and continuing the leverage policy. ${ }^{24}$ However, with its move towards 60 percent enrichment, Iran decidedly demonstrated that it can easily ramp up to 90 percent, if required, and would not be intimidated. The resistance policy was continued. In contrast, during the Obama presidency, Iran's enrichment consistently stayed at or below 3.67 percent as specified under the JCPOA. Mutual respect achieved results.

Iran's fast approaching presidential elections in June 2021 and a shift in political climate proved to be other factors in pushing the Biden administration to abandon its initial plans. Growing support for conservative factions in Iran and clear signs that the new Iranian president will be less receptive to cooperation with the West gave negotiations greater urgency and forced the hand of the Biden administration (who earlier openly expressed willingness to extend talks into the next Iranian presidency). This was a crisis of the U.S.'s own making. The Trump administration's violations and sabotage of the JCPOA only served to radicalize the Iranian position. Without having much result to show for Iranian compliance, President Hassan Rouhani and Iran's reformists were left significantly weakened. Following years of economic hardship and sanctions, the Iranian people became disillusioned with the promised benefits of the JCPOA. ${ }^{25}$ This is why many analysts predicted that Iran's upcoming presidential elections would be dominated by conservatives - similar to Iran's parliamentary elections in $2020 .^{26}$ This prediction ultimately proved true with Ebrahim Raisi's victory in the presidential election. ${ }^{27}$

Meanwhile, following Biden's victory in the 2020 U.S. presidential elections, conservative forces in Iran's parliament passed legislation restricting cooperation with the International Atomic Energy Agency (IAEA) and suspending short-notice inspections of Iran's nuclear sites. ${ }^{28}$ The law outlined an immediate upgrade to 20 percent uranium enrichment and set a deadline of two months to stop allowing inspections beyond the Safeguards Agreement, including the voluntary implementation of the Additional Protocol, if the remaining parties to the JCPOA did not fully deliver on their commitments to Iran, as well as a deadline of three months to install 1000 advanced second-generation centrifuge machines ("IR-2M"), among other measures.

Rouhani's government quickly struck a three-month deal with the IAEA to temporarily postpone parliament's measures, but the political message was clear: Iran is not prepared to wait forever. ${ }^{29}$ This put pressure on negotiators who were now facing a looming deadline. The parties to the JCPOA started to meet much more frequently in desperate attempts to reach an agreement before the expiration of the temporary IAEA deal (and before a new government would take office in Iran). During these meetings, substantial progress was 
made regarding key hurdles that had stalled negotiations before. "Of the main issues that remain disputed, some have been resolved and some remain, but it has taken on a very precise form and it is quite clear what the dimensions of these disputes are", Seyyed Abbas Araghchi, Iran's deputy foreign minister, said. ${ }^{30}$ Iran's firm stance succeeded in convincing the U.S. side to act fast, but ultimately not fast enough.

The key figure who made this recalculation and shift by the Biden administration possible was Robert Malley, the new U.S. special envoy for Iran. ${ }^{31}$ Having served under the Obama administration as one of the lead negotiators of the JCPOA and as a member of the National Security Council, Malley is a veteran diplomat and has proven his expertise regarding Iran and the region many times. Malley's track record that includes his work on dispute resolution at the International Crisis Group proved helpful in shifting the Biden administration's focus from coercion to active diplomacy. His assignment by President Biden demonstrated Biden's commitment to negotiations and was a positive sign that the administration now focused its efforts on preserving the JCPOA.

As serious discussions continued, senior diplomats agreed to meet and extend negotiations seven consecutive times in order to determine whether an agreement can be reached. The next round of negotiations was supposed to take place ${ }^{32}$ after the inauguration of the new Iranian president, Ebrahim Raisi, as the nuclear portfolio had already been handed over to his administration (and the talks resumed in Vienna on November 29 December 3, 2021). None of this would have been possible without a strategic recalculation by the Biden administration. Draconian sanctions imposed on Iran by the Trump administration and its "maximum pressure" policy failed to yield any results and only served to radicalize the Iranian position. Serious discussions only began after a change in approach by the new administration in Washington. However, Biden's delay already proved costly as excessive U.S. pressure empowered Iranian conservatives and enabled them to beat the reformists. Biden lost credibility and trust in the eyes of the Iranian people after failing to immediately lift the same sanctions he had criticized as "cruel" back in April 2020. At that time, he had demanded that the Trump administration ease sanctions on Iran as "the right and humane thing to do" during the pandemic. However, after taking office, he refused to do so himself.

Iran's new parliament proved to be losing patience as well. President Rouhani declared if it had not been for the parliament's new law restricting his government's hand in negotiations, the sanctions would have been lifted by the end of March 2021 (the start of the new Iranian calendar year). ${ }^{33}$ Any new arrangement reached by the negotiating parties would now have to be vetted by Iran's conservatives. This comes after repeated warnings by Iran that Biden's delays would have serious consequences. The U.S.'s reluctance to lift sanctions effectively sidelined the voices of moderation in Iran who are in favor of negotiations with the West. Negotiations were paused for several months until (and after) the new president took office in Iran. Biden lost his chance to negotiate a deal with the Rouhani administration and now had to engage with President-elect Raisi.

Despite conservative leadership, Iran's new government will remain in the JCPOA if world powers also do so. Even Iran's conservatives have now committed to the deal's continuation. However, the days of "strategic patience" advocated by the Rouhani administration are over. ${ }^{34}$ Rouhani's government stayed in the nuclear deal despite all of 
Trump's attempts to sabotage the agreement and U.S.'s repeated violations of the JCPOA. The new government in Iran may not tolerate the same conditions, insisting that world powers demonstrate their full commitment and compliance with the JCPOA so that Iran can see the tangible benefits it was promised. In exchange, Iran will return to full compliance as it has done in the past.

A conservative government in Iran may, however, also imply unique opportunities. ${ }^{35}$ While enjoying the support and trust of Iran's Supreme Leader Ayatollah Khamenei, Iran's new government will not face the same domestic pressures and infighting that the reformist Rouhani team had faced, which could make it easier for Tehran to comply with the JCPOA. The departures of Donald Trump, John Bolton, Mike Pompeo, and Benjamin Netanyahu were all positive signs that also relieved pressure on the nuclear deal. Meanwhile, Saudi Crown Prince Muhammad Bin Salman has been busy engaging in negotiations with Iran. ${ }^{36}$ The past saboteurs of the JCPOA are mostly gone. The world powers should look at this as an opportunity for engagement. This will only be possible if they remain committed to the JCPOA, support innovative regional cooperation system in the Persian Gulf, recognize and respect Iran's natural and sovereign rights, and accept legitimate venues to negotiate regional issues. ${ }^{37}$ Based on the initiative by the UN Secretary General, dialogue between the GCC states, Iran, and Iraq should take place without any preconditions at the level of foreign ministers, with the aim of creating an institutionalized security and cooperation system in the Persian Gulf. Any sustainable partnership must respect sovereignty, non-use of force, territorial integrity, peaceful settlement of disputes, and non-interference in the internal affairs of other countries and include respect for each other's political systems and a commitment to the UN charter as its key principles.

\section{ENDNOTES}

\footnotetext{
${ }^{1}$ Warrick J., Gearan A. Biden has vowed to quickly restore the Iran nuclear deal, but that may be easier said than done // Washington Post. 9 December 2020.

2 Pillar P.R., Reardon R., Sebenius J.K., Singh M.K. Nuclear negotiations with Iran // International Security. 2013. V. 38. № 1. P. 174-192.

${ }^{3}$ Vaez A. Iran's nuclear program and the sanctions siege // Arms Control Today. 2013. V. 43. № 4. P. 8-14. URL: https://www.armscontrol.org/act/2013-05/iran\%E2\%80\%99s-nuclear-program-sanctions-siege (accessed 01.12.2021).

4 Kimball D.G. Don't abandon the Iran Nuclear Deal // Arms Control Today. 2017. V. 47. № 7. P. 3. URL: https://www.armscontrol.org/act/2017-09/arms-control-today/dont-abandon-iran-nuclear-deal (accessed 01.11.2021).

${ }^{5}$ Parsi T. Losing an Enemy: Obama, Iran, and the Triumph of Diplomacy. - New Haven, CT: Yale University Press, 2017.

${ }^{6}$ Mousavian S.H., Mahmoudieh Y. Trump has undone the years of progress in US-Iran relations achieved under Obama // Phelan US Centre Blog on American Politics and Policy. London School of Economics. 25.01.2019. URL: https://blogs.Ise.ac.uk/usappblog/2019/01/25/trump-has-undone-the-years-of-progress-in-us-iran-relationsachieved-under-obama (accessed 01.11.2021).
} 
7 Gearan A., DeYoung K. Biden team exploring how U.S. might rejoin Iran nuclear deal // Washington Post. 5 February 2021.

8 House Foreign Affairs Committee hearing on Biden Administration foreign policy priorities // C-Span. 10.03.2021. URL: https://www.c-span.org/video/?509633-1/house-foreign-affairs-committee-hearing-biden-administrationforeign-policy-priorities (accessed 08.08.2021).

9 Iran's missile programme is non-negotiable, says Rouhani // Reuters. 14.12.2020. URL: https://www.reuters.com/ article/iran-nuclear-usa-int-idUSKBN2801KU (accessed 08.08.2021).

10 The JCPOA “sunset provisions" stipulate when the various restrictions imposed on Iran's nuclear program expire. Under the JCPOA's "sunset" provisions, once key nuclear restrictions expire in years 8, 10 and 15, the Iranians are legally free to build up their uranium enrichment capability and thereby reduce the time it would take to produce nuclear weapons.

11 Mohammed A., Pamuk H. U.S. is some ways from decision on resuming Iran nuclear deal: Blinken // Reuters. 19.01.2021. URL: https://www.reuters.com/article/us-usa-biden-state-iran-idUSKBN29O2HD (accessed 08.08.2021).

12 Full Committee Hearings to Examine the Expected Nomination of Anthony J. Blinken to be Secretary of State. U.S. Senate Committee on Foreign Relations. 19 January 2021. URL: https://www.foreign.senate.gov/hearings/ nominations-011921 (accessed 01.12.2021).

13 Hearing on Pending Nominations. U.S. Senate Committee on Foreign Relations. 3 March 2021. URL: https://www.foreign.senate.gov/hearings/nominations-030321 (accessed 01.12.2021).

14 Rad A., Mortazavi N. President Biden must follow the advice of Candidate Biden on Iran // Foreign Policy. 10 March 2021. URL: https://foreignpolicy.com/2021/03/10/president-biden-must-follow-the-advice-of-candidatebiden-on-iran (accessed 08.08.2021).

15 Macias A. Biden says Iran must return to negotiating table before U.S. lifts sanctions // CNBC. 07.02.2021. URL: https://www.cnbc.com/2021/02/07/biden-says-iran-must-return-to-nuke-deal-before-sanction-relief.html (accessed 08.08.2021).

16 Hafezi P. Iran says U.S., not Tehran, should act first to resolve nuclear deal row // Reuters. 28.01.2021. URL: https://www.reuters.com/article/iran-nuclear-usa-int-idUSKBN29X1ZL (accessed 08.08.2021).

17 Iran's Zarif proposes coordinated return to nuclear deal with US // Al Jazeera. 02.02.2021. URL: https://www.aljazeera.com/news/2021/2/2/eu-official-could-mediate-return-to-iran-nuclear-pact-zarif (accessed 08.08.2021).

18 Iran's Khamenei insists US sanctions must be lifted first // France 24. 22.03.2021.

URL: https://www.france24.com/en/live-news/20210322-iran-s-khamenei-insists-us-sanctions-must-be-lifted-first (accessed 08.08.2021).

19 Iran rejects "step-by-step" lifting of U.S. sanctions // Reuters. 03.04.2021. URL: https://www.reuters.com/ article/us-iran-nuclear-idUSKBN2BQ08I (accessed 08.08.2021).

${ }^{20}$ Gambrell J. Iran starts enriching uranium to 60\%, its highest level ever // AP News. 17.04.2021. URL: https://apnews.com/article/iran-uranium-enrichment-60-percent-ed89e322595004fddc65fd4e31c1131b (accessed 08.08.2021). 
21 Bergman R., Gladstone R., Fassihi F. Blackout hits Iran nuclear site in what appears to be Israeli sabotage // New York Times. 11 April 2021.

22 Faghihi R. Iran's supreme leader voices pessimism about new talks with US // Al Monitor. 13.07.2021. URL: https://www.al-monitor.com/originals/2017/06/iran-sl-khamenei-pessimism-new-talks-us-tehranattacks.html?amp (accessed 08.08.2021).

23 U.S. admits "maximum pressure" policy on Iran failed // Tehran Times. 26 February 2021.

${ }^{24}$ Spetalnick M., Psaledakis D., Pamuk H., Hunnicutt T. Biden will keep using U.S. sanctions weapon but with sharper aim - sources // Reuters. 16.12.2020. URL: https://www.reuters.com/article/us-usa-sanctions-insightidUSKBN28Q1CV (accessed 08.08.2021).

${ }^{25}$ Gallagher N. Iranian public opinion highlights need to redouble efforts to save the JCPOA. European Leadership Network Commentary. 27 February 2020. URL: https://www.europeanleadershipnetwork.org/commentary/ iranian-public-opinion-highlights-need-to-redouble-efforts-to-save-the-jcpoa (accessed 08.08.2021).

${ }^{26}$ Eqbali A., Rasmussen S.E. Iran's Conservatives win elections after record-low turnout, disqualifications // Wall Street Journal. 23 February 2020.

27 Leff A. 4 things to know about Iran's election on Friday // NPR. 17.06.2021. URL: https://www.npr.org/2021/06/ 17/1006848183/4-things-to-know-about-irans-election-on-friday (accessed 08.08.2021).

${ }^{28}$ Iranian Parliament Bill on Nuclear Program: Full Text in English. 3 December 2020 // The National Iranian American Council (NIAC) web-site. URL: https://www.niacouncil.org/publications/iranian-parliament-bill-on-nuclear -program-full-text-in-english (accessed 08.08.2021).

${ }^{29}$ Wintour P. IAEA and Iran strike three-month deal over nuclear inspections // Guardian. 22 February 2021.

30 Jenne Ph., Grieshaber K. Diplomats: progress made in Vienna at Iran nuclear talks // AP. 20.06.2021. URL: https://apnews.com/article/donald-trump-joe-biden-vienna-middle-east-iran-b6506eb091550af63b2097c 3900bb4bf (accessed 08.08.2021).

31 Rezaian J. Opinion: Biden's pick for Iran envoy is a pro. Deal with it // Washington Post. 29 January 2021.

32 Rouhani says nuclear talks will be handed to successor // Al-Monitor. 14.07.2021. URL: https://www.al-monitor. com/originals/2021/07/rouhani-says-nuclear-talks-will-be-handed-successor (accessed 08.08.2021).

33 Mehdi S.Z. Iran starts oil exports from Oman Sea, bypassing Strait of Hormuz // Anadolu Agency. 22.07.2021. URL: https://www.aa.com.tr/en/middle-east/iran-starts-oil-exports-from-oman-sea-bypassing-strait-of-hormuz/ 2311448 (accessed 08.08.2021).

34 Cunningham E. Iran's presidential candidates vow to uphold nuclear deal in televised debate // Washington Post. 5 May 2017.

${ }^{35}$ Vaez A., Esfandiary D. The hard-liners won in Iran. That's not all that bad news // New York Times. 22 June 2021.

36 Parsi T. Why Mohammed bin Salman suddenly wants to talk to Iran // Foreign Policy. 29 April 2021. URL: https://foreignpolicy.com/2021/04/29/saudi-arabia-iran-uae-mohammed-bin-salman-secret-talks-bidenwithdrawal-pivot-middle-east (accessed 08.08.2021). 
37 Mousavian S.H. A New Structure for Security, Peace, and Cooperation in the Persian Gulf. - L.: Rowman \& Littlefield, 2020.

\section{BIBLIOGRAPHY}

Faghihi R. (2017). Iran's Supreme Leader voices pessimism about new talks with US. Al-Monitor, 13 June. URL: https://www.al-monitor.com/originals/2017/06/iran-sl-khamenei-pessimism-new-talks-ustehran-attacks.html?amp (accessed 08.08.2021).

Gallagher N. (2020). Iranian Public Opinion Highlights Need to Redouble Efforts to Save the JCPOA. European Leadership Network Commentary. 27 February. URL: https://www.europeanleadership network.org/commentary/iranian-public-opinion-highlights-need-to-redouble-efforts-to-save-thejcpoa (accessed 08.08.2021).

(2021). House Foreign Affairs Committee Hearing on Biden Administration Foreign Policy Priorities. C-SPAN, 10 March. URL: https://www.c-span.org/video/?509633-1\%2Fhouse-foreign-affairscommittee-hearing-biden-administration-foreign-policy-priorities (accessed 28.08.2021).

(2020). Iranian Parliament Bill on Nuclear Program: Full Text in English. National Iranian American Council (NIAC). 3 December. URL: https://www.niacouncil.org/publications/iranian-parliament-billon-nuclear-program-full-text-in-english (accessed 13.11.2021).

Kimball D.G. (2017). Don't abandon the Iran Nuclear Deal. Arms Control Today. 2017. V. 47. No. 7. P. 3. URL: https://www.armscontrol.org/act/2017-09/arms-control-today/dont-abandon-iran-nuclear-deal (accessed 01.11.2021).

Mousavian S.H. (2020). A New Structure for Security, Peace and Cooperation in the Persian Gulf. London: Rowman \& Littlefield Publ. 192 p.

(2021). Full Committee Hearings to Examine the Expected Nomination of Anthony J. Blinken to be Secretary of State. U.S. Senate Committee on Foreign Relations. 19 January. URL: https://www.foreign.senate.gov/hearings/nominations-011921 (accessed 01.12.2021).

(2021). Hearing on Pending Nominations. U.S. Senate Committee on Foreign Relations. 3 March. URL: https://www.foreign.senate.gov/hearings/nominations-030321 (accessed 01.12.2021).

Parsi T. (2017). Losing an Enemy: Obama, Iran, and the Triumph of Diplomacy. New Haven, CT: Yale University Press. $454 \mathrm{p}$.

Parsi T. (2021). Why Mohammed Bin Salman suddenly wants to talk to Iran. Foreign Policy. 29 April. URL: https://foreignpolicy.com/2021/04/29/saudi-arabia-iran-uae-mohammed-bin-salman-secrettalks-biden-withdrawal-pivot-middle-east (accessed 08.08.2021).

Pillar P.R., Reardon R., Sebenius J.K., and Singh M.K. (2013). Nuclear negotiations with Iran. International Security. V. 38. No. 1. P.174-192.

Rad A. and Mortazavi N. (2021). President Biden must follow the advice of candidate Biden on Iran. Foreign Policy. 10 March. URL: https://foreignpolicy.com/2021/03/10/president-biden-must-followthe-advice-of-candidate-biden-on-iran (accessed 08.08.2021).

(2021). Rouhani says nuclear talks will be handed to successor. Al-Monitor. 14 July. URL: https://www.almonitor.com/originals/2021/07/rouhani-says-nuclear-talks-will-be-handed-successor (accessed 08.08.2021).

Vaez A. (2013). Iran's nuclear program and the sanctions siege. Arms Control Today. V. 43. No. 4. P. 8-14. URL: https://www.armscontrol.org/act/2013-05/iran\%E2\%80\%99s-nuclear-programsanctions-siege (accessed 01.12.2021). 